\title{
Opportunities and Challenges of Private Investment in East Gojjam Zone of Amhara Regional State, Ethiopia
}

\author{
Megbaru Tesfaw Molla ${ }^{1^{*}}$ Abebe Birhanu Ayele ${ }^{2 *}$ \\ 1.College of Business and Economics, Department of Accounting and Finance, Debre Markos University, \\ P. O.Box 269, Debre Markos Ethiopia \\ 2.College of Business and Economics, Department of Banking and Finance, Debre Markos University, P.O.Box \\ 269, Debre Markos Ethiopia
}

\begin{abstract}
The aims to examine opportunities and challenges of private investment activities in East Gojjam zone with the intention of providing valuable information about the investment environment of the zone to the potential investors. In addition to this, the study investigates the trend of private investment in East Gojjam Zone. Descriptive type of research design has been used in this study by giving more emphasis on qualitative data analysis method. On the other hand, quantitative research analysis has been used to provide numerical measurement and analysis of the magnitude and extent of the problem and trend of private investment in East Gojjam Zone. The study used both primary and secondary data. Pre-designed self-administered questionnaire has been used to collect primary data. The investment bureau documents have been used in gathering the secondary data in this study. In order to obtain primary data, a total of 310 questionnaires were distributed to investors found in East Gojjam zone and 305 of them were filled and returned to researchers. In addition, some secondary sources of data were surveyed to know the trend of private investment practices in the zone. The outcome of this study revealed that, the major bottlenecks of investment in East Gojjam zone are Administrative and policy related factors, Infrastructure related factors Macro economic variables which have a nationwide effect, unavailability of foreign exchange reserves and exchange rate fluctuations and Market related factors. Socio cultural factors and Geographic factors are considered as opportunities of private investment in East Gojjam Zone.
\end{abstract}

Keywords: Private Investment, Opportunities, Challenges

DOI: $10.7176 /$ JPID/48-05

\section{Introduction}

According to the report of United Nations Conference on Trade and Development (UNCTAD) (2002), Investment is one of the primary engines of growth in all economies. However, its effectiveness rests on strong complementarities with other elements in the growth process, most notably technological progress, skills acquisition and the development of innovative capability. These elements make investment a natural point of departure for Governments seeking to formulate a robust development strategy. The link between investment and these other determinants of growth, however, is not an automatic process. It requires among other things a favorable macro policy environment and specific policies and institutions aimed at encouraging savings and attracting and directing investment to key sectors in the economy thereby enhancing the contributions of investment to skills formation, technological change, competitiveness and economic growth.

According to the report of the Oakland Institute (2010) Ethiopia has created a very attractive investment climate in recent years by providing potential investors with various tax breaks, access to affordable land, a relatively efficient investment process, very affordable land rents, suitable agro-climatic conditions, low labor costs (labor is cheap and abundant), outstanding incentives, including tax holidays and no duty, relaxed regulations, corruption is low relative to other countries, abundant amounts of "undeveloped" land, strategic location (with respect to markets), abundant water resources, ability to export privileged access to other markets, streamlined investment process. In addition, the Ethiopian government has established a "land bank," further facilitating the process through which investors acquire land. Utilizing the advantage of natural resources for export of high-value agricultural products is the best strategy to achieve rapid economic growth for a country.

Despite the opportunities and potential for investment in Ethiopia, several major challenges were emerged. Among these challenges; infrastructure problems; roads, power, and water, lack of financial and technical assistance to private investors, lack of alternative domestic and regional markets (World Bank, 2004).

The opportunities and challenges of private investment have been substantially studied by different researchers, (Morisset, and Jacques 2000; Basu and Srinivasan, 2002; Salish, and Mohammed, 2003). These and other researchers investigated their study on this area and identified the opportunities and challenges in different countries and areas. However, almost all of these studies conducted on developed and large areas. From such findings it is difficult to generalize the same result in East Gojjam zone. As per the researchers knowledge research studies on the opportunities and challenges of private investment environment in East Gojjam zone remained an ignored area of study. Thus, with these serious shortcomings of the current literature, this study will 
contribute to the existing literature.

East Gojjam zone is among the zones found in Amhara Region which has attractive natural resource. However, with such ample resources availability and investment potentiality within the zone, the investment activities had been carried out was not sufficient as expected.

By considering the above situations, the researchers were motivated to conduct this study to identify opportunities and challenges impeding the private investment activity in East Gojjam zone and to remind the concerned body about these issues. Generally, this study is conducted with the aim of providing answers for the following basic research questions:

1. What are the major opportunities of private investment activities in East Gojjam zone?

2. What are the challenges of private investment that impair the development of private investment in East Gojjam zone?

3. What trend does the private investment in East Gojjam Zone has?

\subsection{Objectives of the study}

\subsection{General objective}

The general objective of the study is to examine opportunities and challenges of private investment activities in East Gojjam zone with the intention of providing valuable information about the investment environment of the zone to the potential investors.

\subsection{Specific objectives}

In addition to the general objective, the study has the following specific objectives:

1. To identify the opportunities of private investment in East Gojjam Zone.

2. To identify the challenges of private investment that impairs the development of private investment activities in East Gojjam Zone.

\subsection{Methodology of the Study}

\subsection{Data Sources and Methods of Collection}

The researchers have employed descriptive type of research design by giving more emphasis on qualitative data analysis method. Qualitative research analysis has been applied to explain the challenges and opportunities of private investment in East Gojjam Zone and to obtain systematic sequence of information to get into the depth of research problems. On the other hand, quantitative research analysis has been used to provide numerical measurement and analysis of the magnitude and extent of the problem. Data for this study were collected from both primary and secondary sources of data. Primary data were obtained from selected investors in East Gojjam Zone and East Gojjam zone investment and trade bureau. Secondary data were obtained mainly from different reports of East Gojjam Zone office, which are relevant to the theme of the study.

Pre-designed self-administered questionnaire has been used to collect primary data. Pre-designed selfadministered questionnaires have been employed and filled by the managers of the investment sectors in East Gojjam Zone to identify the opportunities and challenges of investment in the zone. Interviews have been used to collect data from East Gojjam zone investment and trade bureau. The investment bureau documents have been used in gathering the necessary data in this study.

\subsection{Sample size and sampling techniques}

The study population of this study were identified based on the proclamation number 37/1996; which says investors should have a capital requirement of birr 1,000,000 and above. Thus, in selecting the study population of this study those investors, who has a capital of birr 1,000,000 and above were included in this study. Based on the report of East Gojjam zone investment bureau from 1,797 total investments in East Gojjam Zone 1365 are in six selected woredas (Debre Markos, Mota, Bichena, Dejen, Amanual and Debre Elias).

The researchers have employed both purposive and stratified sampling techniques to select the actual sample size from the total study population. Generally, the actual sample size of any study is depending on the total population, the research budget and the available time to accomplish the study. Given these in to account, the study utilized the following sample size determining formula to set the actual sample size scientifically (Yaro Yamane, 1967).

$$
n=\frac{N}{1+N\left(e^{2}\right)}
$$

Where $\mathbf{n}=$ The actual sample size

$\mathbf{N}=$ The total population

$\boldsymbol{e}=$ Degree of accuracy usually set at 0.05 
The formula states:

$$
\mathrm{n}=\frac{\mathrm{N}}{1+\mathrm{N}(\mathrm{e}) 2}=\frac{1365}{1+1365\left(0.05^{2}\right)}
$$

Sample woredas were selected purposively from east Gijon zone based on their number of investment. For the purpose, six woredas which possess high number of investment were selected. Then, using business types as strata, sample respondents were selected proportionately from each selected woredas. Sample respondents was those investors which were under operation at least for the previous one year period and still are in operation at the time of undertaking the survey.

From the total population of 1365 investors in the six selected woredas of east Gojjam zone (Debre Markos, Mota, Bichena, Dejen, Amanual and Debre Elias), sample of 310 investors were taken as sample respondents based upon the above formula. The sample proportion of each woreda determined by their respective population size is given in the table below.

Table 2: Sample size determination by woredas

\begin{tabular}{|l|l|l|l|}
\hline Woredas/towns & Population & Sample proportion & Actual Sample \\
\hline Debre Markos & 714 & $52.32 \%$ & 162 \\
\hline Mota & 349 & $25.58 \%$ & 79 \\
\hline Bichena & 159 & $11.63 \%$ & 36 \\
\hline Dejen & 48 & $3.49 \%$ & 11 \\
\hline Amanual & 32 & $2.33 \%$ & 7 \\
\hline Debre Elias & 63 & $4.65 \%$ & 15 \\
\hline Total & $\mathbf{1 , 3 6 5}$ & $\mathbf{1 0 0 \%}$ & $\mathbf{3 1 0}$ \\
\hline
\end{tabular}

\begin{tabular}{|c|c|c|c|c|c|c|}
\hline \multirow[t]{2}{*}{ Town } & \multicolumn{6}{|c|}{ Sector } \\
\hline & Manufacturing & Construction & Urban Agriculture & Service & Trade & Total \\
\hline D/ Markos & 67 & 7 & 11 & 14 & 63 & 162 \\
\hline Mota & 32 & 4 & 5 & 7 & 31 & 79 \\
\hline Bichena & 15 & 2 & 2 & 3 & 14 & 36 \\
\hline Dejen & 4 & 1 & 1 & 1 & 4 & 11 \\
\hline Amanual & 2 & 1 & 1 & 1 & 2 & 7 \\
\hline D/ Elias & 6 & 1 & 1 & 1 & 6 & 15 \\
\hline Total & 126 & 16 & 21 & 27 & 120 & 310 \\
\hline
\end{tabular}

The researchers identified the actual sample of each town by each sector. The table below also shows the actual sample size in each town for their respective investment sector.

\subsection{Methods of Data Analysis and Interpretation}

The process of data analysis is assisted by making use of the computer aided software available, mainly for analyzing the quantitative data. The relevant computer software [SPSS Ver. 16] has been used as a tool to manage the quantitative data. The respondents' scores is summarized and analyzed using both simple statistical techniques such as tables, charts, percentages etc. and descriptive statistics like the mean, standard deviation. Using tables, graphs and percentages as the basis of interpretation the researchers have interpreted data after analysis.

\subsection{Conceptual framework of the study}

As presented in the empirical literature review section above, the major factors which affect private investment, positively or negatively, are summarized as follows below in a conceptual framework section.

a. Infrastructure: Involves the presence or absence of basic investment infrastructures like access to electricity, road, airport, water \& sewerage, telecommunication and communication linkage, hotel and hostel.

b. Administration factors: More focuses on the transparency and ease accessibility of management or administration system and style for investment in the study area such as investment regulation and policy, access to investment area(land), anti-corruption and disclosures, improved local management skill, employment opportunities, institutional environment, government services and technical assistance.

c. Infrastructural factors: related to facilities of telecommunication, electricity, road, water, postal and health facilities.

d. Financial and institutional factors: related to provision of capital (fund) and accessibility to insurance in order to finance and insure the investment activities at minimized risk. The factors included here are access to finance \& capital leverage (credit), insurance services, long-term finance, security of life and property, risk minimization mechanisms and political stability.

e. Socio-cultural factors: considers core values and customs of the community like level of education, their 
awareness about investment, religion, belief, and tradition.

f. Geographic factors: focuses on the strategic location, urbanization, accessibility to alternative investment and climatic conditions of the area.

g. Market related factors: considers the accessibility to main market and demand for its products or services, for instance, strategic linkage to consumer, quality, existence and price of inputs, involvement in and accessibility to export market.

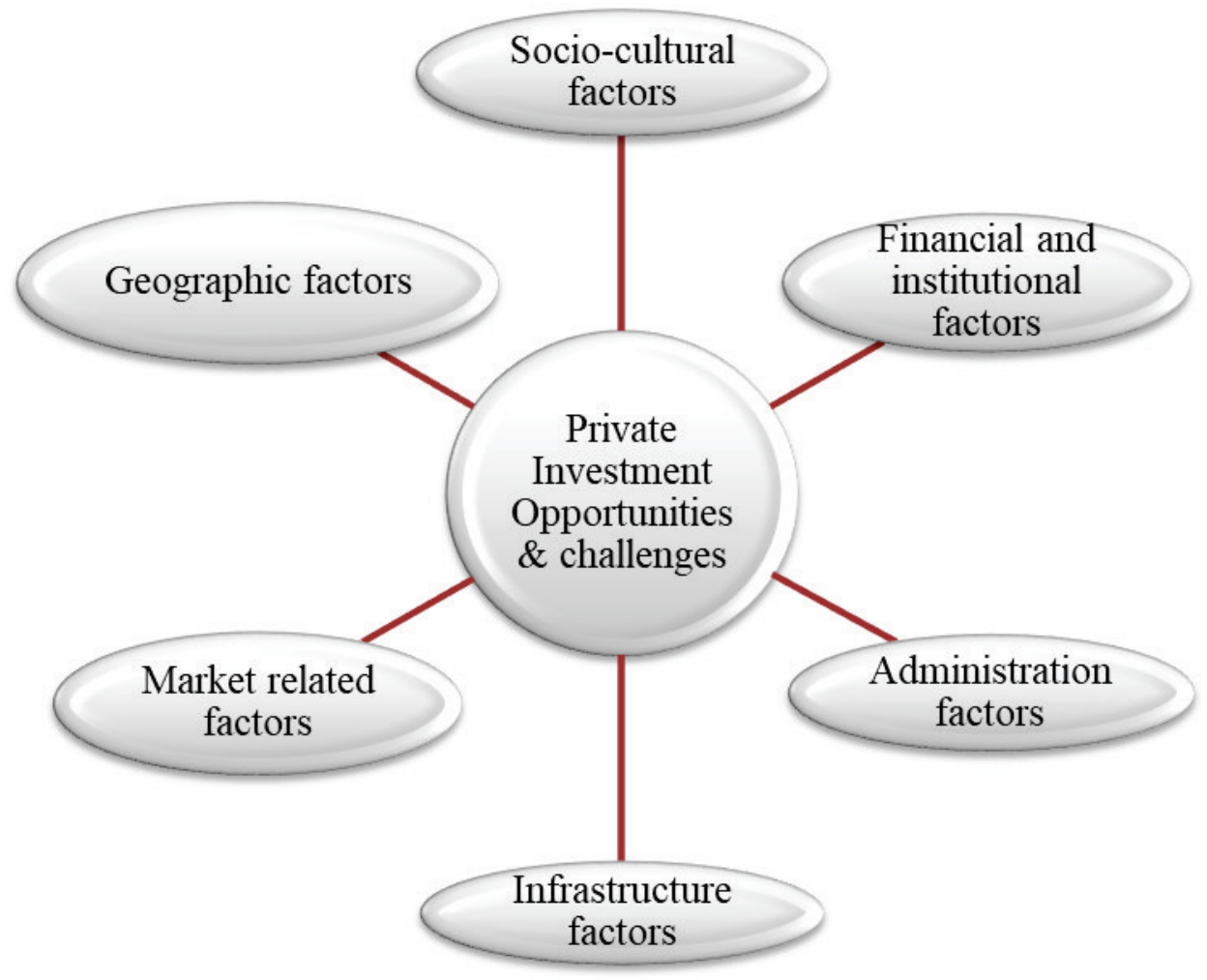

\subsection{Results and Discussion}

\subsection{Challenges of Private Investment}

The main factors which are considered to be challenges of private investment are depicted in the following part of analysis. These factors are categorized in to six subdivisions: administrative and policy related factors, the physical and other infrastructural barriers, factors related to access to finance, socio-cultural factors, geographical factors and market related factors. The respondents were asked to give Likert scale value for these factors from 1- 5(strongly disagree to strongly agree) depending on the degree of challenge of these variables. If the mean score value of the analysis is below 3, it indicates the variables are opportunities of private investment in East Gojjam Zone while if it is above 3, the variable are factors which affect private investment in East Gojjam Zone. Accordingly, the mean value of each variable was computed and summarized below: 


\subsubsection{Administrative and Policy Related Factors Affecting Private Investment}

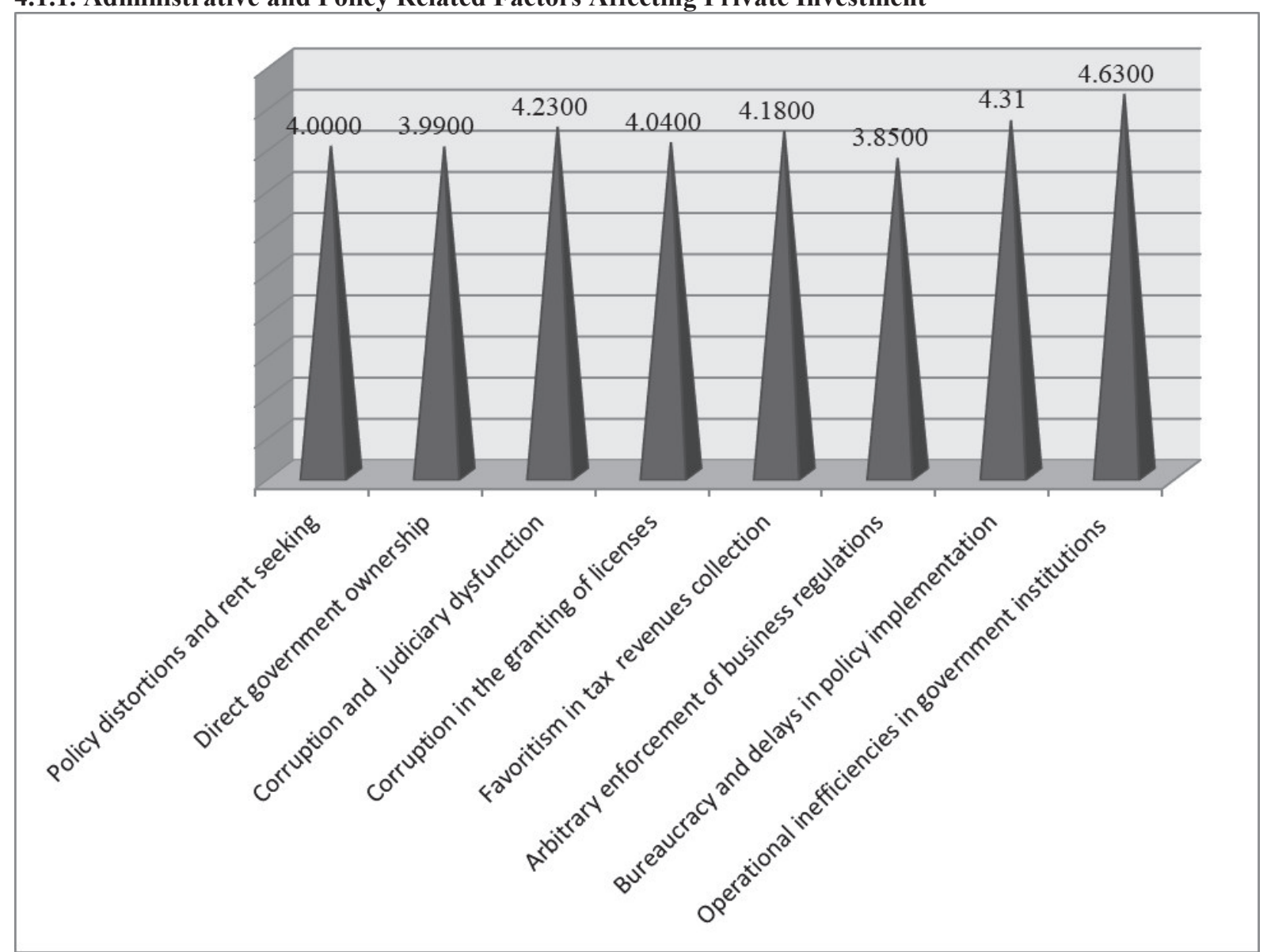

Chart: 4.1. Administrative and Policy Related Factors

As per chart 4.1: above, administrative and policy related factors like policy distortions and rent seeking, direct government involvement in some investment areas, corruption and dysfunction of the judiciary system, malpractices in granting licenses of investment activities, favoritism in tax revenue collection, arbitrary and inappropriate enforcement of business regulations, bureaucracy and policy implementation delay have brought major hindrances on the investment activities in East Gojjam zone all having a mean score of around 4.00 and close to 4.00. This means, majority of the investors in the zone agree that the above administrative and policy related factors are their major problems for their investment activities. Among these factors, operational inefficiencies of those government institutions is considered as the main obstacle by majority of private investors in the study area having a mean value of 4.63 which close to 5 . That is they strongly agree that operational inefficiencies of some government offices which have affinity of investment activities deter significantly their investment practices. Emery (203), apparently clarifies the quality of governance directly affects the level and nature of private investment in a given country. He explained the relationship of governance to private investment is complex and is subject to many influences governance/ administrative issues like policy distortions, rent seeking, use of direct government ownership for political and patronage objectives, corruption and dysfunction of the judiciary system, corruption in the granting of investment licenses, tax collection favoritism, and others significantly affect investment in the private sector. degree of openness, previous value of inflation rates and governance indicators are the most important factors but political stability and voice and accountability indicators appear to dominate the governance indicators space as they are both negative and significantly affecting the private investment mobilization (Ajide ,2013). Likewise, unpredictable and inefficient investment climate (which could be due to reasons such as frequent changes of investment policies and requirements, inefficient bureaucracy, prolonged poor governance and rampant corruption among others), would deteriorate investors' confidence and appetite (Adugna, 2013)

\subsubsection{Infrastructure and other Factors}

According to chart 4.2: below, except unavailability of working age people in the investment area, other factors which include electricity, water supply, inadequate transport and communication system, unavailability of health and educational facilities are all problems of private investment in the study area. Particularly, adequate electric energy, water supply and transportation and communication having a mean score of 4.91, 4.76, and 4.69 are 
considered as pillars of private investment by majority of by majority of the respondents as their mean value is close to 5.00. Access to education and health facilities have a relatively less degree of influence compared to the above variables as their mean values are close to 4:00. Unavailability of working age people is considered as a problem for private investment in the area as its mean score is close to 2:00. This means, this variable can instead be an enabling condition/ opportunity for private investment in the zone. The results of different studies substantiate our findings. Samuel (2011), highlighted Government Capital Spending and Financing and its Impact on Private Investment in Kenya identified that Investment in infrastructure has an insignificant positive effect on private investment in Kenya. public infrastructure (represented by the kilometres of roads per capita) is found to have a positive effect on private investment in the short run (Pradyumna 2013)

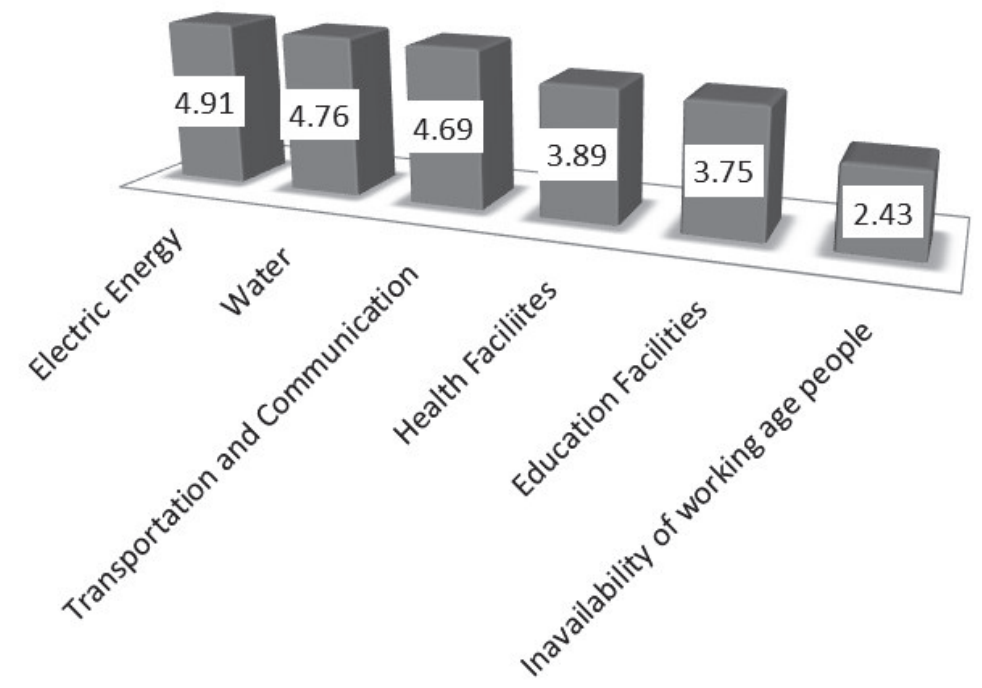

Chart 4.2. Infrastructure and others

\subsubsection{Finance Related Factors Affecting Private Investment}

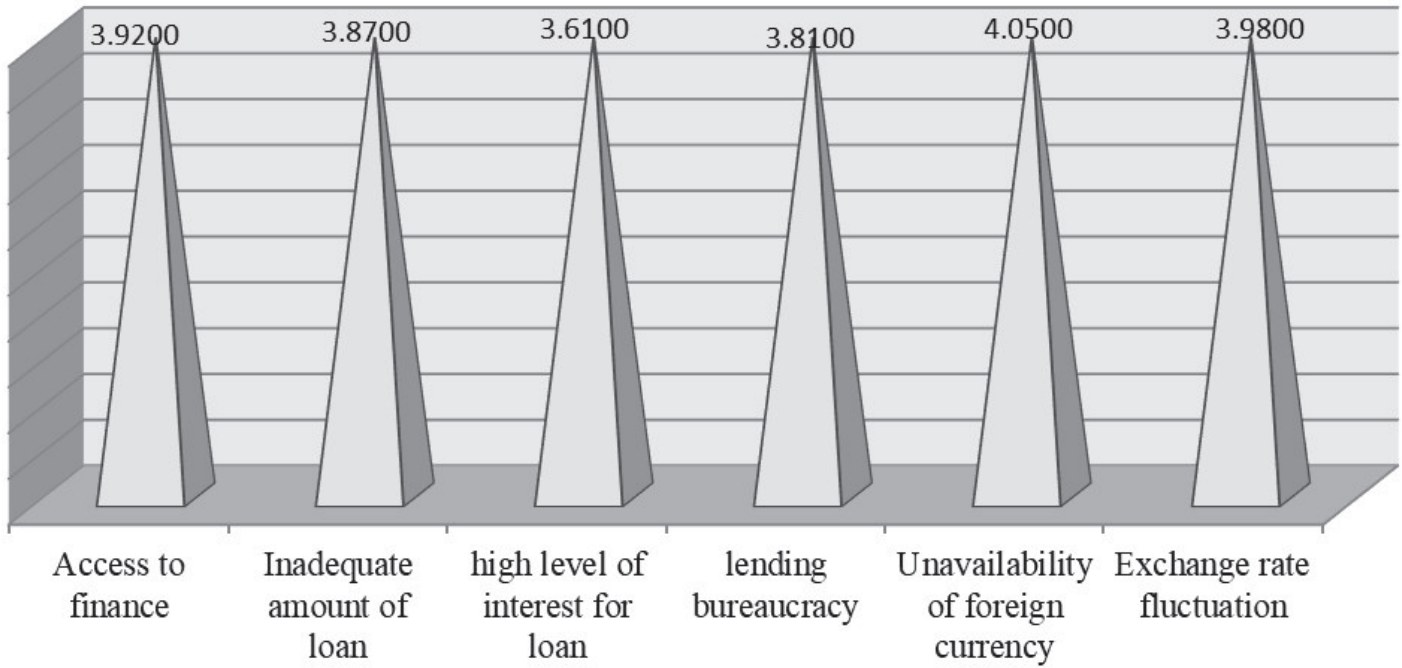

Chart: 4.3. Finance Related Factors

The degree of challenge investors faced with finance related factors is depicted by the above chart 4.3. Though they are macro economic variables which have a nationwide effect, unavailability of foreign exchange reserves and exchange rate fluctuations are the main problems hamper their investment activities in the study area having a mean score of 4.05 and 3.98 respectively which are close to 4.00 (agree). This means that majority 
of the investors agree that shortage of foreign currency, particularly the USD, and fluctuations of exchange rates significantly discourages their investment. Other variables which include access to credit in formal financial institutions, inadequate amount of loan, high interest rates, and bureaucracy of lending institutions to give loan are all affecting investment practices in East Gojjam zone significantly having a mean value of $3.92,3.87,3.61$ and 3.81 which are very close to 4.00 (agree). Compared to the previous two finance related factors, they bring a lesser influence up on investors' activities in the zone. Findings of earlier studies made in different parts of the world support our findings. For instance, investment credit, interest rates, inflation have negative significant effect on private investment (Nainggolan, et al, 2014). Exchange rate, access to credit, inflation rate, money supply are among those variables affecting the performance of private investment (Muhidin 2016). Lack of adequate credit will bring a reduction in reduction in the level of private investment with adverse effect on the long term productive capacity of the private sector (Kehinde et.al. 2012))

Policies like deepening financial liberalization, improve the efficiency of the commercial banking system, promote deepening of capital markets, scale up support to SME financing through partial credit guarantees, promote financial innovation, promote creation of credit bureaus etc are need to be done so as to increase business enterprises' access to credit (Fiestas and Sinha , 2011). Acosta and Loza (2005), also highlighted expected rates of return, real exchange rate, inflation although its immediate impact seems to stimulate investment, with time, the effect seems to vanish and become negative are important determinants of private investment in the short run. Credit availability allows higher levels of private investment.

\subsubsection{Socio-cultural Factors Affecting Private Investment}

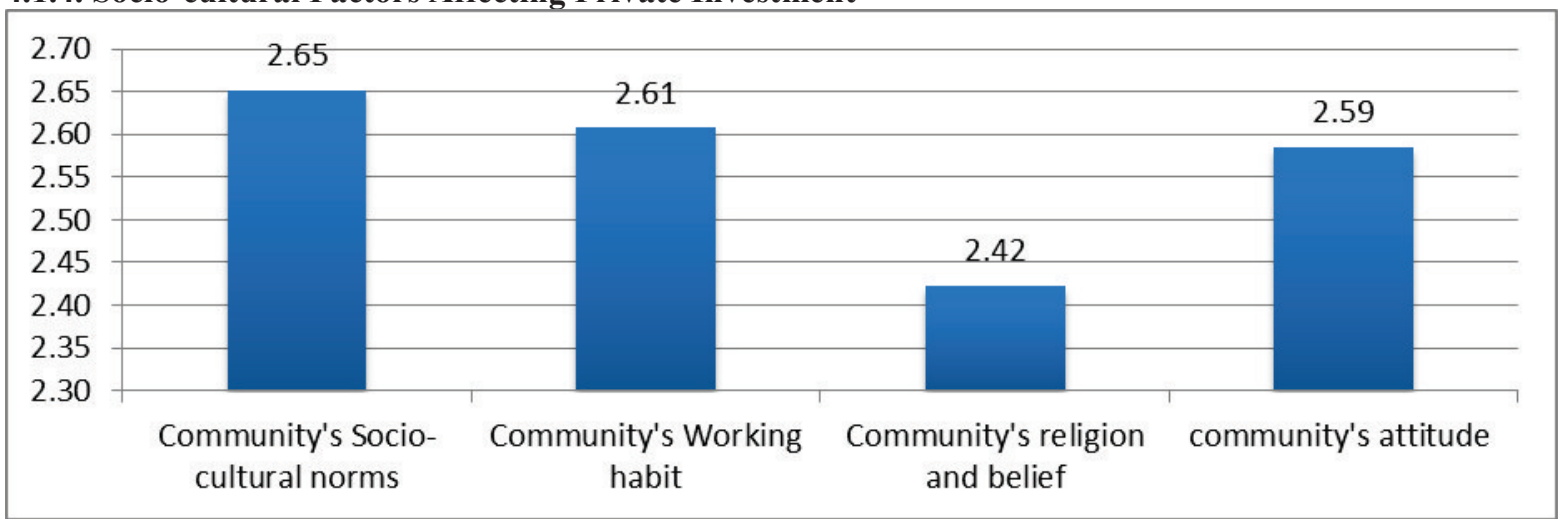

Chart 4.4 Socio-cultural Factors Affecting Private Investment

Chart 4.4 above; indicates the mean score values for Community's attitude, Community's religion and belief, Community's working habit and Community's Socio-cultural norms are 2.59, 2.42, 2.61 and 2.65 respectively. All mean scores of Socio-cultural Factors Affecting Private Investment are below 3, which indicate respondents disagreed that those factors does not affect private investment. So, East Gojjam Zone has good opportunity of Community's attitude, Community's religion and belief, Community's working habit and Community's Socio-cultural norms towards private investment. This outcome supports the outcomes found by Akhter and Sumi (2014) which, advocates socio-cultural factors can influence positively entrepreneurial emergence in a society.

\subsubsection{Geographic Factors Affecting Private Investment}

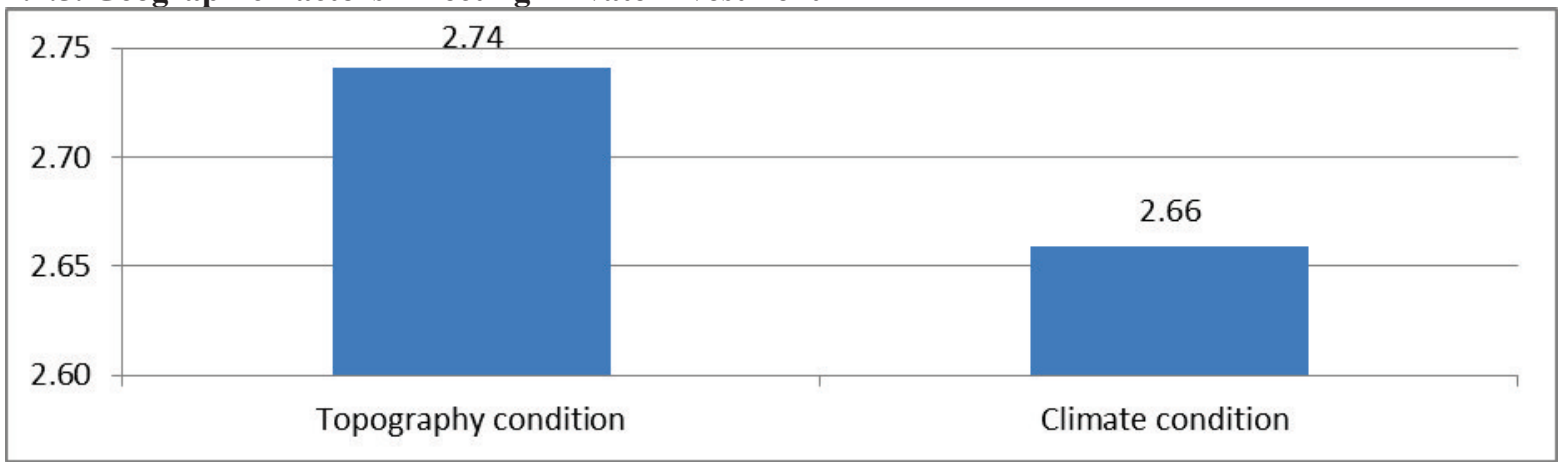

Chart 4.5. Geographic Factors Affecting Private Investment

As chart 4.5. above shows, the mean score for climate condition and topography condition are 2.66 and 2.74 respectively as geographic factors which affects private investment in East Gojjam zone. These mean scores values of Geographic Factors Affecting Private Investment are below 3, which indicate respondents disagreed that these factors does not affect private investment even if, East Gojjam zone is far from the central part of Ethiopia by 299 K.M . So, East Gojjam Zone has good opportunity of climate condition and topography 
condition towards private investment as responded by respondents.

\subsubsection{Market Related Factors Affecting Private Investment}

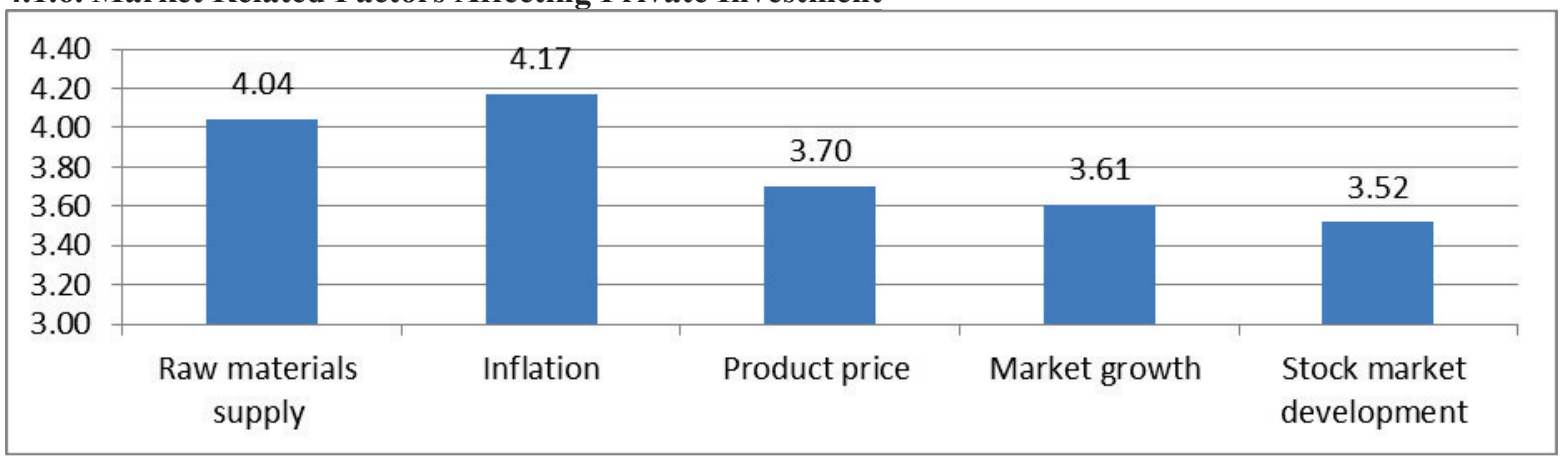

Chart 4.6. Market Related Factors Affecting Private Investment

Chart 4.6. above; indicates the mean score values for stock market development, market growth, product price, inflation and raw materials supply are 3.52, 3.62, 3.70, 4.17 and 4.04 respectively. This value indicates that, respondents replied that respondents agreed that all those market related factors affect private investment in East Gojjam Zone.

Even though, the mean score value for all market related factors indicates as those factors which affects private investment in East Gojjam zone, the degree of effects of variables are different. The degree of effects of stock market development, market growth and product price is minimum as the mean score values for this factors are between 3 and 4 while the degree of effects for factors inflation and raw materials supply is strong as the vales are between 4 and 5 .

To sum up the discussion on market related factors which affects private investment in East Gojjam zone, stock market development, market growth and product price affects private investment in East Gojjam Zone and inflation and raw materials supply strongly affects private investment in Esat Gojjam Zone. This outcome supports the outcomes found by Kodithuwakku et al. (2016), Naje (2013), Grace et al, (2016) and World Bank Development report (2005).

\section{Conclusions}

Several studies have been conducted so far on the investigation opportunities and challenges of private investment activities. And the outcome of these research studies was mixed from place to place. The purpose of this study is to examine opportunities and challenges of private investment activities in East Gojjam zone with the intention of providing valuable information about the investment environment of the zone to the potential investors.

Administrative and policy related factors like policy distortions and rent seeking, direct government involvement in some investment areas, corruption and dysfunction of the judiciary system, malpractices in granting licenses of investment activities, favoritism in tax revenue collection, arbitrary and inappropriate enforcement of business regulations, bureaucracy and policy implementation delay have brought major hindrances on the investment activities in East Gojjam zone. Among these factors, operational inefficiencies of those government institutions are considered as the main obstacle by majority of private investors in the study area.

Infrastructure related factors such as Electricity energy, water, transportation and communication, health facilities, education facilities and unavailability of working age people are investigated whether they are factors or opportunities of investment. Electricity energy, water, transportation and communication, health facilities, education facilities are considered as obstacle by majority of private investors in the study area, except unavailability of working age people in the investment area which is opportunity of investment in the area.

Macro economic variables which have a nationwide effect, unavailability of foreign exchange reserves and exchange rate fluctuations are the main problems hamper their investment activities in the study area. Other variables which include access to credit in formal financial institutions, inadequate amount of loan, high interest rates, and bureaucracy of lending institutions to give loan are all affecting investment practices in East Gojjam zone significantly.

Socio cultural factors such as Community's attitude, Community's religion and belief, Community's working habit and Community's Socio-cultural norms and Geographic factors such climate condition and topography condition as does not affect private investment even if, East Gojjam zone. These variables are considered as opportunities of private investment in East Gojjam Zone.

Market related factors such as stock market development, market growth, product price, inflation and raw materials supply have brought major hindrances on the investment activities in East Gojjam zone. Among these factors, inflation and raw materials supply are considered as the main obstacle by majority of private investors in 
the study area.

The overall investment size IN East Gojjam one from the year 2006 E.C up to 2010 E.C is in an increasing rate even though East Gojjam zone has a number of challenges as we have discussed in the above analysis of opportunities and challenges of Private investment in East Gojjam Zone.

\section{References}

Gebremeskel Awet Wedaj et al. (2015) Assessment of private investment in tigray, northern Ethiopia: challenges and opportunities in the case of manufacturing sector: InternationalJournal of Current ResearchVol. 7, Issue, 01, pp.12210-12217.

Basu, et al (2002), Foreign Direct Investment in Africa - Some Case Studies. IMF Working Paper 61.

Hailu Adugna (2013) Determinats of private investment in Ethiopia, Journal of Economics and Sustainable Development ISSN 2222-1700 (Paper) ISSN 2222-2855 (Online) Vol.4, No.20, 2013

Korolev p, (2010).potential opportunities for investors, Mekelle, Ethiopia. KPMG International.

Majeed, M.T. and S. Khan (2008) 'The Determinants of Private Investment and the Relationship between Public and Private Investment in Pakistan', Journal of Businessand Economics

Morisset\& Jacques (2000), "Foreign Direct Investment in Africa: Policies Also matter." Transnational Corporation, 9(2), 107-125.

MuhdinMuhammedhussenBatu. Determinants of Private Investment: A Systematic Review. International Journal of Economics, Finance and Management Sciences. Vol. 4, No. 2, 2016, pp. 52-56. doi: 10.11648/j.ijefm.20160402.13

PinondangNainggolan,et.el, An Analysis of Determinant on Private Investment in North Sumatra Province, Indonesia, Journal of Management Research ISSN 1941-899X2015, Vol. 7, No. 1

Oakland Institute's (2010). Understanding land investment deals in Africa: Ethiopia.

Pfeffermann, G.P. and A. Madarassy (1992) 'Trends in Private Investment in DevelopingCountries': International Finance Corporation: The World bank, Washington D.C.

Salisu, \& Mohammed (2003), Foreign Direct Investment in Sub-Saharan Africa, The management School, Lancaster University.

UNCTAD (2002). Investment and innovation policy review in Ethiopia. www.oaklandinstitute.org.

World Bank, (2004).Opportunities and challenges for developing high-value agricultural exports in Ethiopia.

Kehinde .O.et al . 2012. The Determinants of Domestic Private Investment in Nigeria. IOSR Journal of Humanities and Social Science (JHSS)

Emery J. James . 2003. Governance, Transparency and Private Investment in Africa. Global Forum on International Investment. Johannesburg, South Africa

Agidew Esubalew Tadele. 2014. Determinants of Domestic Private Investment; Evidence from East Africa; International Institute of Social Studies

Ajide Kazeem Bello. 2013. The Role of Governance on Private Investment in Nigeria: A Preliminary Analysis, Central Bank of Nigeria Economic and Financial Review Volume 51

Adugna Hailu. 2013. Determinants of Private Investment in Ethiopia, Journal of Economics and Sustainable Development, Vol.4, No.20.

Acosta, P., \& Loza, A. (2005). Short and Long Run Determinants of Private Investment in Argentina. Journal of Applied Economics, 2(8), 389-406.

Fiestas. I and S. Sinha (2011) 'Constraints to Private Investment in the Poorest Developing Countries' a Review of Literature'. Department for International Development, London UK.

Akhter Rahma and Sumi Farhana Rahman . 2014. Socio-Cultural Factors Influencing Entrepreneurial Activities: A case Study in Bangladesh, IOSR Journal of Business and Management, Volume 16, Issue 9.Ver. II

Nnabuike O..Osadebe, 2015. Socio-cultural Factors Affecting the Performance of Micro and Small Scale Enterprises in Anambra and Abia States, Nigeria.

Clobanu R. and Bahna M.2015.The Social, Cultural and Political Factors that Influence the Level of Mergers and Acquisitions, International Journal of Academic Research in Accounting, Finance and Management Sciences, Vol 5, No.3.

Kodithuwakku, D., Yasasi W., Jayawardhana, M., Muhandiramge K. \& Dulani, K., (2016) Study on the factors affecting private investments in Sri Lanka: Journal of Social Statistics 2016

Najeb.M.(2013)The Impact of Stock Market Performance upon Economic Growth:International Journal of Economics and Financial Issues Vol. 3, No. 4, 2013, pp.788-798

Jan, D. (2000) Private Investment in Developing Countries: the Effects of Commodity Shocks and Uncertainty: Centre for the Study of African Economies.

Udo, N. (2013) Determinants of Private Investment in Nigeria: An Empirical Exploration: Journal of Economics and Sustainable Development, ISSN 2222-1700 (Paper) ISSN 2222-2855 Vol.7, No.11, 2016. 
Najeb, M. (2013) The Impact of Stock Market Performance upon Economic Growth International Journal of Economics and Financial Issues Vol. 3, No. 4, 2013, pp.788-798

World Bank Development report (2005) Infrastructure and Financial Sector Development: ISBN 92-64-02586-3 Policy Framework for Investment A Review of Good Practices (C) OECD 2006

Organization for Economic Cooperation and Development Annual Report (2006)https://www.oecd.org/newsroom/36511265.pdf

Grace, O., Eugenia, A. \& George, A. (2016) Does Stock Market Development Enhance Private Investment in Ghana?:International Journal of Humanities and Social Science Research, 2016, 2, 68-78

Peter, H. (2010) People and Places: Can They Align to BringGrowth to Africa?, center for global development essay, www.cgdev.org/content/publications/detail/1424441

Stephen, G., Charles, O., Nelson, W. \&Nelson W., (2014) Impact of Government Expenditure on Private Investment in Kenya: Researchjournali’s Journal of Economics Vol. 2 | No. 8 August | 2014 ISSN 23478233

Yaw, A. (2000) Determinants of Private Investment Behavior:The African Economic Research Consortium P.O. Box 62882 Nairobi, Kenya

Mohammad, B. and Salma, A. (2005) The investment scenario in Bangladish-problems and prospects: Pakistan Journal of social science 3(4): 534-540:2005.

Samuel, o. (2011) Government Capital Spending and Financing and its Impact on Private Investment in Kenya:1964-2006: The African Economic Research ConsortiumP.O. Box 62882 - City Square Nairobi 00200, Kenya

Pradyumna, D. (2013) the impact of public investment on private investment:evidence from India: VIKALPA The Journal for Decision Makers 41(4) 288-307

Conference Board of Canada (2013) The Economic Impact of Ontario's Infrastructure Investment Program: Briefing April 2013: Conference Board research at www.e-library.ca

Guerin S. (2002) The Role of Geography in Financial Integration: Foreign Direct Investment. JEL classification: F36; F21

Trkulja, Jovana, "Geographic Factors as Determinants of Foreign Direct Investment in Eastern Europe's Transitioning Economies" (2005).Geography Honors Projects.Paper 4.

DeVellis, R.F. (2003). Scale development: Theory and applications (2nd edn). Thousand Oaks, California: Sage. 